\title{
材料〔III
}

1. 超高真空用金属材料（高木祥示）2. 無機材料一ガラス材料（鈴木巧一・尾山卓司）3. 有機材料一ポン プ油（赤田民生） 4. 有機材料一機能材料（野口正敏）5. ガス材料と利用技術（松本 功）

\section{3. 有機材料一ポンプ油}

\section{1 はじめに}

現在真空技術は半導体製造, 核融合, 宇宙開発, 粒子 加速機, 太陽電池, 航空機, 自動車, 新材料開発, 生体 関連物質, オプトエレクトロニクスなどきわめて幅広い 領域にわたる先端技術分野を支える基礎技術のひとつと して利用されている.

これらの産業の中で目的とする真空環境を作るために 種々の真空ポンプが利用されている. たとえば真空ポン プ油を必要とするものとしては機械的な作用によって気 体を排気する機械的ポンプ, 蒸気の噴流で排気作用を行 なら蒸気噴射ポンプなどがあり, 又油を使用しないもの としては低温面での吸着現象, ゲッタ及び放電や高速回 転する羽根による分子運動などを利用して気体を排気す るドライポンプがある.

近年ではメンテナンスコストの低減や油分子の逆流に よる製品污染の問題解決の手段として, 真空ポンプのド ライ化が進んでいる.しかしながらドライポンプも油を 使用しないことによる長所はあるが，利用の手軽さやコ ストの面から見れば油を用いる真空ポンプの役割もまだ まだ重要であるといえる.

作動油を必要とする真空ポンプの能力を最大限に発揮 させるには, 真空ポンプ油の適切な選択と正しい使い方 が不可欠である.

ここでは真空ポンプ油として利用できる有機材料の種 類と特長及び選定の目安について紹介する.

\section{2 有機材料の種類と特長}

\section{2 .1 鉱 油}

潤滑油留分は多種多様な化学構造を有する炭化水素の 混合物であるが, パラフィン系, ナフテン系, 芳香族系 に大別することができる. パラフィン系は粘度指数が高 く, 潤滑油として優れた性能を有する. 芳香族系は高温 下でスラッジを発生し, 粘度指数が低いため好ましくな
い。ナフテン系は両者の中間の性質をもっている，

鉱油系真空ポンプ油は主としてパラフィン系の潤滑油 を蒸留することによって得られる. 蒸留条件は要求する 粘度と蒸気圧のものが得られるように設定される。

機械的ポンプ油は無添加タイプ, 添加タイプ, 流動パ ラフィン系の 3 種類に分類される. 添加タイプは鉱油の 酸化安定性や潤滑性を向上させるために種々の添加剂が 配合されたものであるが，これらの添加剤は蒸気圧が高 いものが多く，限られた用途にしか使用でさない，

流動パラフィンは不飽和結合をもたないことから弱い 活性ガスに対しては鉱油に比べて若干安定である ${ }^{1)}$.こ のことを応用して半導体製造プロセスで使用されている 例もあるようである。

\section{2 .2 合成油}

合成油ではシリコン油, フェニルェーテル油, フッ素 油などが真空ポンプ油として使用される。これらはいず れも鉱油では解決することができない蒸気圧，粘度指 数, 熱安定性, 酸化安定性, 化学薬品性, 放射線性など の特性を改善するため開発されてきたものである。

a ) シリュン油

シリコン油は分子中に $\mathrm{Si}-\mathrm{C}$ と $\mathrm{Si}-\mathrm{O}$ をち, $\mathrm{Si}$ の原 子半径が大きいことから， C- $\mathrm{C}$ 結合に比べて分子屈曲 性が大きい。したがって粘度指数の大きい油である. 、

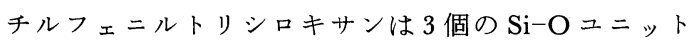
と,メチル基又はフェニル基が結合した 8 個の $\mathrm{Si}-\mathrm{C} ユ$ ニットからなり, 熱安定性, 酸化安定性に優れ, 蒸気圧 が低いことから拡散ポンプ油に広く用いられている。

航空作動油として開発されたポリシロキサンはロータ 一ポンプに応用されたことがあるが, 表面張力が約 $21 \times$ $10^{-5} \mathrm{~N} / \mathrm{cm}$ と低く, ぬれ性はよいが油膜強度が弱く， 潤滑性が良くない22ため実用には至っていない。

潤滑性を改善するためにメチル基の代りに長鎖アルキ ルにした变性シリコンも検討されたが逆に熱安定性や粘 度指数が悪くなる．塩素やフッ素などのハロゲンを分子 中に導入し潤滑性を高めることも検討されている.

b) フェニルェーテル油

フェニルェーテル油は芳香環を酸素原子で結合した構 
表3.1 代表的な機械的ポンプ油の種類と性状

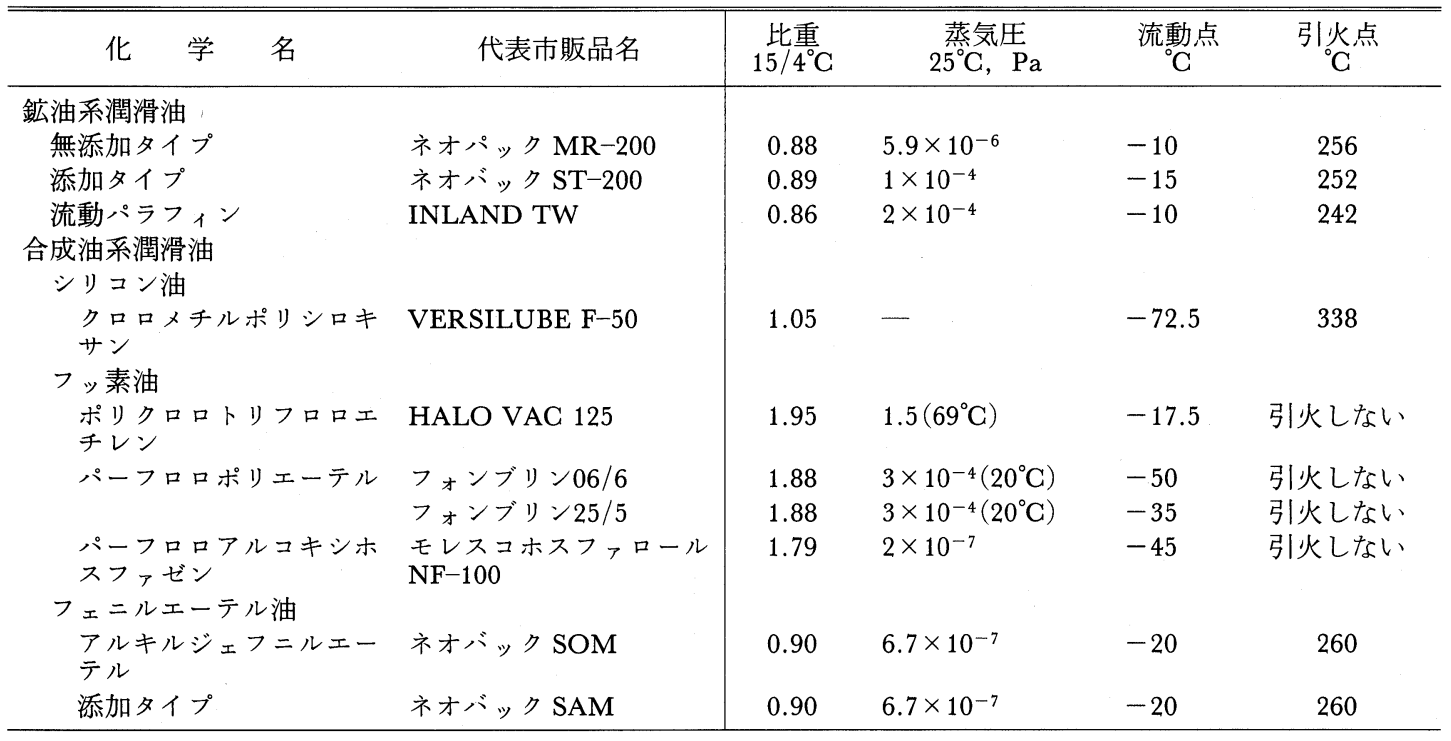

造をもち, その共鳴構造により, 熱安定性, 酸化安定性 に優れている.

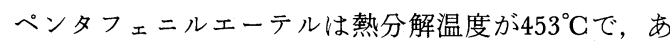
らゆる液状有機化合物の中では, 最高の耐熱・耐酸化性 をもち ${ }^{3,4)}$, 蒸気圧も低いことから拡散ポンプ油として 最適である，乙かし粘度指数が低く，流動点が高いなど の欠点もある.

適当な炭素数の長鎖アルキルを付加したアルキルフェ ニルェーテルは蒸気圧, 粘度指数, 流動点などの物性を 改善できるが，熱安定性は低下する.

側鎖炭素数12〜18のモノアルキルジフェニルェーテル は拡散ポンプ油に適した性能を持つ. ジアルキルジフェ ニルェーテルはロータリポンプ油に適した物性をもつ. 酸化防止剤を配合することにより，鉱油では得られない 耐活性ガス性をもたらすことができる.

c）フッ素油

フルオロカーボンは G-F 結合の結合エネルギーが C-H のそれより大きいため, 高温での安定性が優れて おり, 不燃性でもある. 又化学的に不活性な物質である ことも大きな特長である.

クロロフルオロカーボンは熱安定性, 耐化学薬品性に 優れていることから, これらの特性が必要なロータリ一 ポンプ油に期待されたが，フッ素原子の原子半径が水素 原子のそれより大きいため分子屈曲性が小さく，粘度指 数が悪いため実用例は少ない.

パーフロロポリェーテルは分子内にェーテル結合を多 く含むため分子屈曲性が大きく，優れた粘度指数をもっ ている. フッ素油のもつ基本的な特性も維持しており,
精留により蒸気圧の低いものも取出すことができるので 拡散ポンプ油及びロータリポンプ油として使用できる.

フルオロアルコキシホスファゼンは優れた耐化学薬品 性を有し, 不燃性であることからパーフロロポリェーテ ルに匹敵する油として検討されている.これはフルオロ アルコキシ基の酸素の $\alpha$ 位の炭素にフッ素が存在しな いため, $\mathrm{AlCl}_{3}$ のよらなルイス酸によって塩素化され ず，有害な分解生成物を発生しない（5)という特長があ る.

\section{3 真空ポンプ油の選択}

\subsection{1 機械的ポンプ油}

機械的ポンプに使用される油はケースとロータ用のシ ール作用とベアリング，ギヤ及びその他の摺動部分の潤 滑を行なうものである. 又回転部分より発生する熱を吸 収しポンプの冷却も同時に行なっている.

機械的ポンプ油は排気ガスとの反応性がなく, シール に必要な粘度をもち, 蒸気圧が低いことが選定のポイン トである。

ロータリポンプ油はその働きから高真空側に露出され るので蒸気圧が高いと油蒸気を放出することになり，到 達圧力が悪くなったり，污染が問題となる場合がある.

表3.1に市販の代表的な機械的ポンプ油の種類, 商品 名, 物性を示した。一般の使い方では大部分が鉱油系で 十分であるが，耐化学薬品性，耐放射線性など鉱油では 満足できない特殊環境下ではフッ素油やフェニルェーテ ル油が使用されている。

たとえば半導体製造プロセスでは種々の活性ガスをロ ータリポンプで排気するため, 鉱油系では短時間で分 
表3.2 代表的な拡散ポンプ油の種類と性状

\begin{tabular}{|c|c|c|c|c|c|}
\hline 化 & 市 販 品 名 & $\begin{array}{l}\text { 比重 } \\
15 / 4^{\circ} \mathrm{C}\end{array}$ & $\begin{array}{c}\text { 蒸気圧 } \\
25^{\circ} \mathrm{C}, \mathrm{Pa}\end{array}$ & $\begin{array}{c}\text { 引火点 } \\
{ }^{\circ} \mathrm{C}\end{array}$ & $\begin{array}{c}\text { 蒸発潜熱 } \\
\mathrm{J} / \mathrm{g}\end{array}$ \\
\hline \multicolumn{6}{|l|}{ 鉱油系作動油 } \\
\hline 炭化水素油 & APIEZON C & 0.87 & $1 \times 10^{-6}$ & & 218 \\
\hline \multicolumn{6}{|l|}{$\begin{array}{c}\text { 合成油系作動油 } \\
\text { シリコン油 }\end{array}$} \\
\hline $\begin{array}{l}\text { テトラフェニルテトラメチル } \\
\text { トリシロキサン }\end{array}$ & DC-704 & 1.07 & $3 \times 10^{-6}$ & 210 & 220 \\
\hline $\begin{array}{l}\text { ペンタフェニルトリメチルト } \\
\text { リシロキサン }\end{array}$ & DC-705 & 1.09 & $4 \times 10^{-8}$ & 210 & 220 \\
\hline \multicolumn{6}{|l|}{ フェニルェーテル油 } \\
\hline \multirow[t]{2}{*}{ ペンタフェニルェーテル } & モレスコエクセロール54 & 1.20 & $1 \times 10^{-9}$ & 288 & 205 \\
\hline & サントパック 5 & 1.20 & $4 \times 10^{-8}$ & 288 & 205 \\
\hline $\begin{array}{l}\text { アルキルジフェニルェーテル } \\
\text { フッ素油 }\end{array}$ & ネオバック SX & 0.93 & $7 \times 10^{-6}$ & 260 & - \\
\hline パーフロロポリエーテル & フォンブリン $25 / 9$ & 1.90 & $3 \times 10^{-7}$ & 引火しない & 29 \\
\hline
\end{tabular}

解, 重合などの化学変化を引きおこすため, 油交換の頻 度が高く，生産性が著しく低下する。不然性であるフッ 素油は化学薬品性が優れており寿命は長いが高価格であ る. 寿命は劣るが経済的な油にアルキルジフェニルェー テルがある.

また原子力産業でも真空技術の利用が検討されてい る.この場合は油の耐放射線性が要求される. 放射線に 対する耐性に優れているアルキルジフェニルェーテルは このような放射線場での応用が期待できる.

\section{3 .2 拡散ポンプ油}

拡散ポンプ油はその排気機構から蒸気圧が低く, 熱安 定性に優れていることが必要である。

表3.2に市販の拡散ポンプ油の概要を示した.

現在拡散ポンプを利用している種々の産業では, 生産 性を高めるために, 冷却時間の短縮を行なっている. そ の結果油は高温化下で空気と接触し, 酸化劣化が激しく なる、鉱油系では耐熱・耐酸化性に限界があることか ら，アルキルジフェニルェーテル，メチルフェニルトリ シロキサン, ペンタフェニルエーテル，パーフロロポリ エーテルなどが使用されている。それぞれ耐熱・耐酸化 性は優れているがメチルフェニルトリシロキサンは分解 による $\mathrm{Si}$ の絶縁被膜污染, ペンタフェニルェーテルは このような污染はない(6)が高価格，パーフロロポリエー テルは分解による腐食物質の生成などの問題点をかかえ ている。

\section{3. 真空グリース}

前項まで真空ポンプに用いられる時について述べてき たが，これら以外の真空材料として真空グリースがあ る.

真空グリースはドライポンプの軸受部及び真空装置内
の接合部のシール材や回転・摺動部分の潤滑剤に利用さ れている。

真空グリースに要求される性能は油の場合とほとんど 変らないため, これまで紹介してきた油を基油とし，増 稠剤によりグリース化したものが使用できる.

この場合増稠剤としてはシリカゲルやPTFEが一般 的であるが蒸発性の物質が含まれると, 真空系内が污染 されることがあるので注意する必要がある。

市販品には鉱油系，シリコン系，フッ素系グリースな どがあるが，最近では更に超高真空で用いることがで き, 潤滑油の良いフェニルェーテル系のグリースも検討 されている。

\section{5 おわりに}

今回紹介した有機材料はそれぞれ長所と短所をもって いることから目的に応じて最適の材料を選定する必要が ある。

一方真空技術は先端科学技術分野の基礎技術であり， 今後益々応用範囲は広がっていくものと考兄られ, 油や グリースへの要求は厳しくなるであろう。このような真 空技術の発展に対応すべく，新素材開発が望まれる.

\section{〔文献〕}

1) J. Vac. Sci. Technol. A2(2), Apr.-June 1984.

2） F. P. バウデン，D. テイバー（曾田範宗訳）：“固体 の摩擦と潤滑”，丸善，(1961).

3) Blake, E. S.: J. Am. Eng. Data, 6, 87 (1961).

4) Wjlson, D. R., Benzing, R. J. et al.: Ind. Eng. Chem., Orod. Res. Develop., 6, 81 (1967).

5）多田，村松：真空，28, 9 (1985).

6）佐久間：潤滑，20,7 (1975). 


\section{4. 有機材料一機能材料}

\section{1 はじめに}

最近の電子, 精密機械, 自動車等々の工業製品におい て，有機材料の代表的なエンジニアリングプラスチック が，その特徵を巧みに生かして使用されており，その用 途は更に拡大の一途をたどっている.

一方，先端産業や研究，開発に欠かせなくなった，真 空機器においては如何であろらか.

低〜高真空領域では，合成樹脂の第 1 号と言われるフ ェノール樹肥を始め, 比較的多くの有機材料が使用され てきたが，超高真空領域では，材料自身の分子構造上の 特性のために，限られた種類が，比較的に低い温度条件 でのみ使用されるに過ぎない。

真空用材料として要求される基本特性としては, 本講 座でも既に述べられているが，改めて上げると，

1）ガス放出率

2）ガス透過率

3）最高使用温度に打ける蒸気圧

4) ポロシティー

5）耐酸化性

6）高温（低温）強度

7）熱による分解性

で,これに被削性，接合性等の加工特性が加味され，更 にシステムとして要求される物理的特性（熱伝導率，透 磁率, 誘電率, etc.) が考慮される.

超高真空を得るには，構成材料の表面や固体内部に吸 着, 吸蔵している気体分子（原子）を如何に低減するか が，極めて重要で，そのために必ずベーキングが行われ る. しかし, 有機材料は, 超高真空システムの主要構成 材料であるステンレス鋼等の金属材料のベーキング温度 に対して十分な耐熱性を持っていない，又，ガス放出 率，ガス透過率については，一般には，桁違いに大きな 值を示す。

それでも，実験装置では，有機材料の優れた高弾性， 低摩擦係数, 電気的絶縁性及び加工性に着目し, プラス チックでは，四フッ化ェチレンに樹脂（商品名，テフロ ン), ポリイミド樹脂（商品名, ベスペル, カプトン 等), エラストマーとしては, フッ素ゴム（商品名，バ イトン A), パーフロロエラストマー（商品名, カルレ ッツ) 等が, 軸受, 摺動部品, 絶縁用スペーサー, ガス

\footnotetext{
* Masatoshi NOGUCHI
}

日電アネルバ(侏)
ケット，O-リング等として使用されている.

又, シーラントとして, 低蒸気圧のエポキシ樹脂（商 品名, Torr seal, スーパーバックシール) やシリューン 系樹脂（商品名, Vac seal）の接着剤が，実験室におけ る, 溶接部, ロ一付部等の突発的に発生した真空リーク に対し，暫定対策としては便利で，良く利用される。

以下，これ等の有機材料の真空用材料としての特性及 び関係する事項について述べる.

\section{2 プラスチック}

低〜高真空領域で使用可能なプラスチックの真空特性 については, いろいろ報告されているが1 5), 超高真空 領域で使用可能な種類は，極めて少なく，フッ素樹脂 (PTFE) とポリイミド樹脂ぐらいである。これも，金 属に比較すると十分ではないが，表面積が小さい部品と して使用する限りでは，加工性が良く利用価值は高い.

一般にプラスチックは, 網状高分子構造か, 線状高分 子構造で出来ていて, 前者は, フェノール樹脂やェポキ シ樹脂のように加熱して, 高分子構造に結合すると, 再 度加熱しても，軟らかくなることはないが，後者は，ポ リエチレンやフッ素樹脂のよらに加熱冷却によって流動 状態, 固化状態が可逆的に変化する特性を持っている. 又，機械的強度を高めたり，低摩擦，耐摩耗等の特別な 機能を持たせるために，ガラス繊維，炭素繊維，二硫化 モリブデン $\left(\mathrm{MoS}_{2}\right)$ 等を混ぜた複合材料がある.

最近のプラスチックの主なものを工業材料としての観 点から分類したものを，表4.1に参考に示す6). 新しい プラスチックが使用可能かは, 熱転移点（融点）と，ガ ス放出率に強く影響している吸水率を判断の目安にする ことが出来る。吸水率は, 試験片を蒸留水中に 24 時間浸 漬し増加重量の百分率で表わし，一般に， $0.1 \sim 0.3 \%$ 程 度である。この值から考えても，真空材料としては，限 られることが推測出来る.

4.2.1 四フッ化エチレン樹脂（PTFE）

デュポン社（USA）で開発され，テフロンの商品名 で良く知られている。溶融点 $327^{\circ} \mathrm{C}, 400^{\circ} \mathrm{C}$ 以上で熱分 解し有毒なフッ素を生じるが，使用可能な温度は $-80^{\circ} \mathrm{C} \sim 200^{\circ} \mathrm{C}$ と広く他の樹脂に比較し優れている. 又, 吸湿性はほとんどない。

荷重による塑性変形が生じ易く, 従って, ガスケット として使用する場合には溝付フランジ用として使用し， $35 \mathrm{~kg} / \mathrm{cm}^{2}$ 以下の荷重で使用する必要がある7).

PTFEは, 熱可塑性高分子より成り, 結晶性, 非晶性 の層構造を有している。この非晶質部はすべり易く，そ れによって摩擦係数が低く，鋼に対して0.2程度の值を 
表4.1 エンジニアリングプラスチックの分類6)

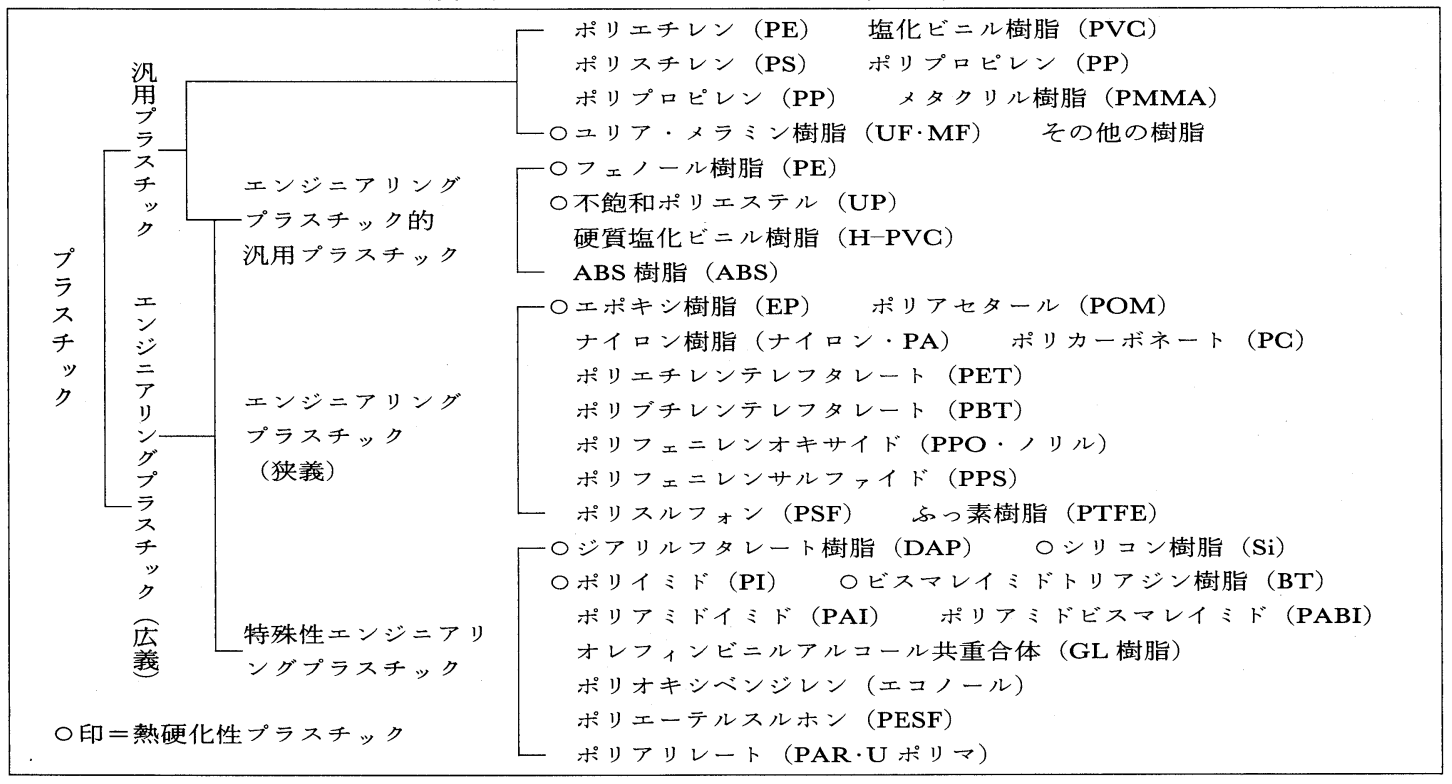

示す。しかし，その反面，摩耗を増加させる原因とな る. 摩擦を低減し, 軸受として重要な寸法安定性を向上 させるため, ガラス繊維, $\mathrm{MoS}_{2}$ を添加した複合材が市 販されている．ガラス繊維の添加による摩耗量の低減は 著しく $1 / 100 \sim 1 / 1000$ にもなると報告されている8 . 熱 可塑性プラスチックの摩擦係数は, 比較的, 雾囲気の影 響を受けにくく，図4.1に示すよらに，真空，大気での 顕著な変化はない.

PTFE の真空特性については，いくつかの報告がある が9,10)，アセトンで脱脂し，24時間排気後，6×10-9 Torrl/sec $\mathrm{cm}^{2}$ と比較的に良いガス放出率を示している ${ }^{11)}$. 主な放出ガス種は， $\mathrm{M} / \mathrm{e}=28 ， 18 ， 44$ である. 又，ガス 透過率も大きく ${ }^{12,13)}$, 特に, 複合材については, 生産口 ットによる差が生じるようである.フッ素樹脂としては, PTFE 以外に 6 種類あり ${ }^{6,14)}$, 特性上の差の大きいもの もあり注意する必要がある.

\subsection{2 ポリイミド樹脂 (PI)}

イミド基を持つ, 全芳香族ポリイミドで, デュポン社 （USA）よりベスペルの名称で市販されている. 現在実 用化されているプラスチック中最高の耐熱性がある. 連 続使用温度 $260^{\circ} \mathrm{C}$, 最高使用温度 $482^{\circ} \mathrm{C}$, 溶融点がなく, 機械的強度, 潤滑性, 耐クリープ特性, 寸法安定性等に ついて金属材料に迫る特性を持っているが，加水分解性 があり，吸水率はPTFEより大きく $0.24 \%$ あ。機械加 工性も良く，素材として，丸棒，チューブ，板等も市販 されている5). ガス放出率については，吸水率が大きい

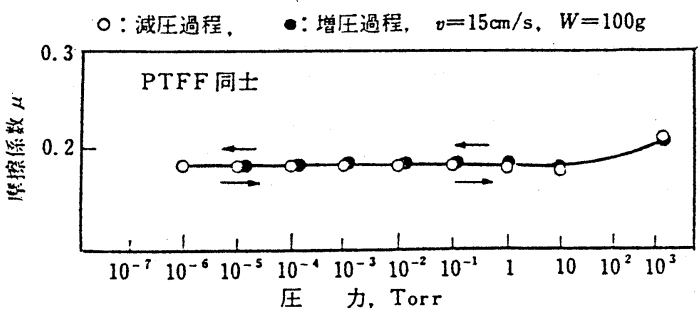

図4.1 PTFE 同士の摩擦係数に及ぼす圧力の影響8)

ため, ベーキングしない場合は, $6 \times 10^{-8}$ Torr $l / \mathrm{sec} \mathrm{cm}^{2}$ であったものが, $300^{\circ} \mathrm{C} 12$ 時間ベーキング後で, $3 \times$ $10^{-11}$ Torr $l / \mathrm{sec} \mathrm{cm}^{2}$ に低減した報告もある16). ポリイミ ドの真空特性については, 実際に, 超高真空用ゲートバ ルブを製作した報告書に詳しい17)。

ポリイミドは, 真空中で $300^{\circ} \mathrm{C}$ 程度までの加熱が可能 で, 超高真空システムで使用出来る. 熱硬化性のプラス チックである．又，耐放射線特性も良好で， $10^{9} \mathrm{rad}$ 程 度の照射では特性の劣化は生じない. 表4.2に PTFE と ポリイミドの主要特性, 図4.2亿残留ガススペクトルを 示す.

\section{3 エラストマー}

通常, 超高真空システムのフランジ等の取りはずし可 能な部分のシールには，金，無酸素銅等の金属製ガスケ ットが使用されるが，到達圧力，ベーキングの程度によ っては，フッ素ゴム系のエラストマーが使用される. ガ 
表4.2 PTFE，ポリイミド主要特性4,5)

\begin{tabular}{|c|c|c|c|}
\hline & 単位 & PTFE & ポリイミド $(\mathrm{SP}-1)$ \\
\hline 重 & - & $2.13 \sim 2.22$ & $1.36 \sim 1.43$ \\
\hline 融 点 & ${ }^{\circ} \mathrm{C}$ & 327 & なし \\
\hline 最高使用温度 & ${ }^{\circ} \mathrm{C}$ & 260 & 360 \\
\hline 吸水 率 & $\%$ & $<0.00$ & 0.24 \\
\hline 線 膨張 係数 & $1 /{ }^{\circ} \mathrm{C}$ & $10 \times 10^{-5}$ & $5 \sim 5.4 \times 10^{-5}$ \\
\hline 引張り強さ & $\mathrm{kgf} / \mathrm{cm}^{2}$ & $140 \sim 350$ & $738 \sim 878$ \\
\hline 伸 び & $\%$ & $200 \sim 400$ & - \\
\hline 硬 & ショア & $\mathrm{D} 50 \sim \mathrm{D} 65$ & $45 \sim 50\left(\begin{array}{lll}\text { 口 } & ッ & ク \\
\text { ウェル } & \mathrm{E}\end{array}\right)$ \\
\hline 耐 電 圧 & $\mathrm{V} / \mathrm{mil}$ & 480 & 490 \\
\hline 体積固有抵抗 & $\mathrm{Ohm}-\mathrm{cm}$ & $>10^{18}$ & $10^{14} \sim 10^{15}$ \\
\hline
\end{tabular}

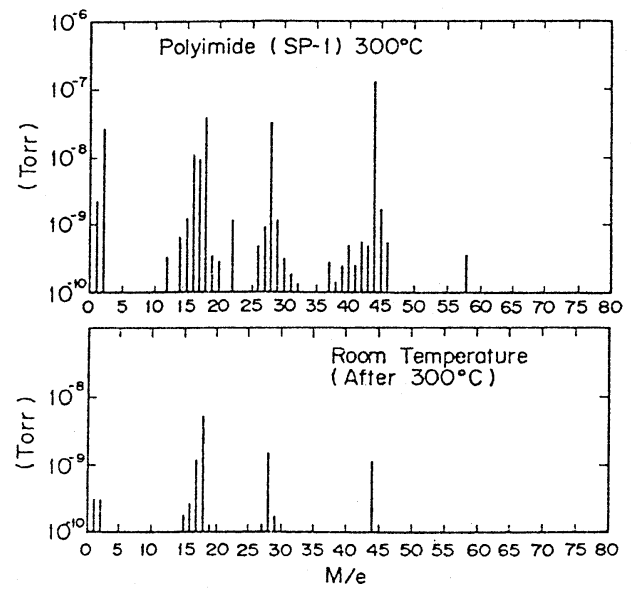

図4.2 ポリイミド（ベスペル SP-1）による残留 ガススペクトル17)

スケットとしてのェラストマーの重要な特性は, 弾性, 硬度, 圧縮永久歪, ガス放出率で, ガス放出率, ガス透 過率については，プラスチックと同様，ガス分子は解離 することなく, 分子状で吸蔵, 透過し, 大きな值を示 し，種類によっては使用に耐えない。超高真空で使用 可能なエラストマーは ${ }^{18)}$, ガス放出率, ガス透過率, 及 び耐熱性で制限され，フッ化ビニリデン〜へキサフルオ ロプロピレン系のゴムであるバイトン $\mathrm{A}$ とパーフロロ エラストマーのカルレッツの 2 種類である ${ }^{19 \sim 26)}$. 前者 については，相当品が国内のゴムメーカーでも製造され ている. 有機材料については, 同種類の相当品がいろい ろのメーカーで製造されているが，相当品だからと言っ て, 真空特性も同じと速断するのは危険である. 超高真 空装置に怙ける材料トラブルがシステムの全体へ与える 影響は重大な問題へと発展する恐れもある。

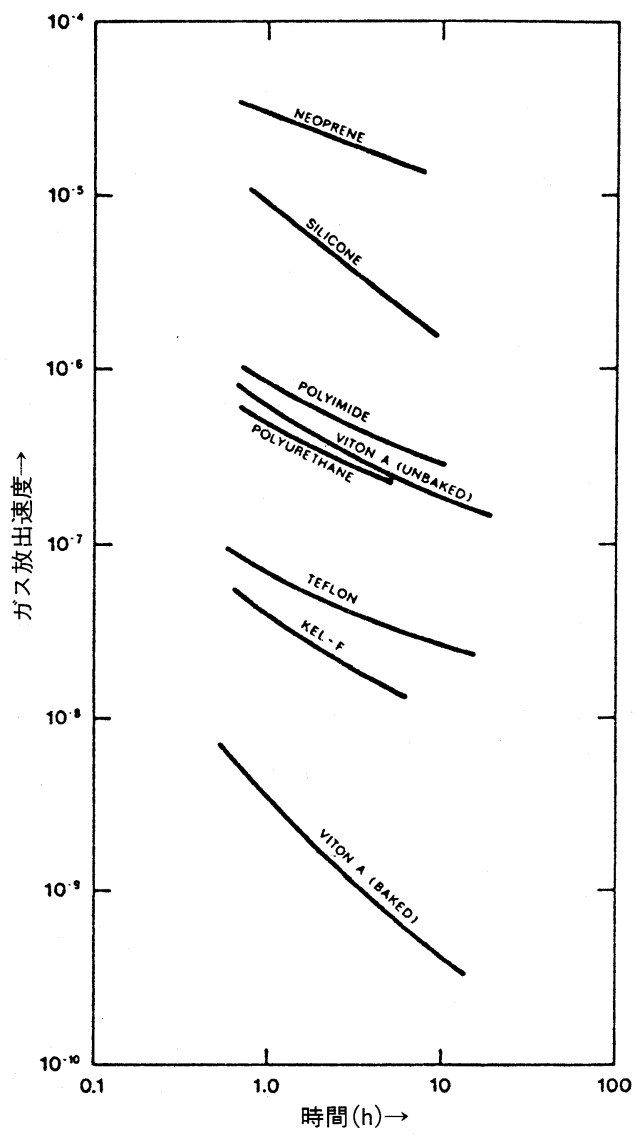

図4.3 各種ポリマーのガス放出率 ${ }^{16)}$

\subsection{1 フッ素ゴム}

デュポン社によって開発された，バイトン $\mathrm{A}$ ，及び圧 縮永久歪を改善したバイトン $\mathrm{E}-60 \mathrm{C}$ が, 従来, 超高真 空用として評価されてきた。最高使用温度は $270^{\circ} \mathrm{C}$ と言 われているが，Oーリングとして使用した状態では， ： イトン $\mathrm{A}$ は $150^{\circ} \mathrm{C}$, バイトン $\mathrm{E}-60 \mathrm{C}$ で $200^{\circ} \mathrm{C}$ のベーキン グ温度には耐える. ガス放出率は $10^{-7} \sim 10^{-6}$ Torr $l / \mathrm{sec}$ $\mathbf{c m}^{2}$ 程度で，前処理条件によって大幅に变化する．特に 吸湿性があるため, 大気中で加熱乾燥するだけでも相当 の低減が出来る. しかし, 脱ガス処理をした，Oーリン グを大気中に放置すると，数時間で，元の状態に戻って しまう，又，使用する前の O-リングの溶剤によるクリ 一ニングは十分に注意しないと，ガス放出として長期間 残ることがある.フッ素ゴムは，エステル，ケトン類に 対して耐性がない16). 図4.3にガス放出率を，表4.3に各 種ポリマーのガス透過率を示す.

4.3.2 パーフロロエラストマー

これも, デュポン社で開発され，テフロンとフッ素ゴ 
表4.3 各種ポリマーのガス透過率 ${ }^{16)}$

単位: $\mathrm{sccm} \mathrm{s}^{-1} \mathrm{~cm}^{-2} \mathrm{cmatm}^{-1}$

\begin{tabular}{l|ccccc}
\hline \hline \multicolumn{1}{c|}{ Polymer } & $\begin{array}{c}\text { Helium } \\
\left(\mathrm{K} \times 10^{8}\right)\end{array}$ & $\begin{array}{c}\text { Nitrogen } \\
\left(\mathrm{K} \times 10^{8}\right)\end{array}$ & $\begin{array}{c}\text { Oxygen } \\
\left(\mathrm{K} \times 10^{8}\right)\end{array}$ & $\begin{array}{c}\text { Carbon dioxide } \\
\left(\mathrm{K} \times 10^{8}\right)\end{array}$ & $\begin{array}{c}\text { Water } \\
\left(\mathrm{K} \times 10^{8}\right)\end{array}$ \\
\hline Fluoroelastomer & $9-16$ & $0.05-0.3$ & $1.0-1.1$ & $5.8-6.0$ & 40 \\
Buna-N & $5.2-6$ & $0.2-2.0$ & $0.7-6.0$ & $5.7-4.8$ & 760 \\
Buna-S & 18 & $4.8-5$ & 13 & 94 & 1800 \\
Neoprene & $10-11$ & $0.8-1.2$ & $3-4$ & $19-20$ & 1400 \\
Butyl & $5.2-8$ & $0.24-0.35$ & $1.0-1.3$ & $4-5.2$ & $30-150$ \\
Polyurethane & - & $0.4-1.1$ & $1.1-3.6$ & $10-30$ & $260-9500$ \\
Propyl & - & 7 & 20 & 90 & - \\
Silicone & - & - & $76-460$ & $460-2300$ & 8000 \\
TEFLON & - & 0.14 & 0.04 & 0.12 & 27 \\
KEL-F & - & $0.004-0.3$ & $0.02-0.7$ & $0.04-1$ & - \\
Polyimide & 1.9 & 0.03 & 0.1 & 0.2 & - \\
\hline
\end{tabular}

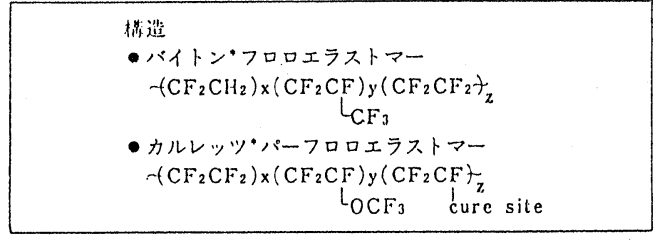

図4.4 バイトンとカルレッツの分子構造 ${ }^{34)}$

ムの両者の長所を持っている. 最高使用温度は $250^{\circ} \mathrm{C}$ 程 度で，バイトンょり更に高い温度にて安定である．耐薬 品性については, 塩素化炭化水素系溶剂に弱いので, 注 意が必要，ガス放出率は，ベーキングしないで，1時間 の排気後 $3 \times 10^{-9}$ Torr $l / \mathrm{sec} \mathrm{cm}^{2}$ ベーキング後の到達の 值で, $3 \times 10^{-11} \sim 3 \times 10^{-10}$ Torr $l / \mathrm{sec} \mathrm{cm}^{2}$ と小さな值であ る ${ }^{16)}$. 又放射線に対しても，バイトンより $40 \%$ 改善され ている27)。このように，大半の特性は良いが，問題は高 価なことである．図4.4にバイトン，カルレッッの分子 構造, 表4.4にカルレッッの主要特性を, 又, 図4.5, 4. 6にガス放出のスペクトルを示す.

\section{4 シーラント}

超高真空装置は，長時間のベーキングの繰返しを行ら ため, 時々, 突発的なリークが発生したり, 内部機構が 破損したりする。そんな時に，注意して使えば，重宝す るのがシーラントである.

シリコーン樹脂系のシーラントは, $4 \times 10^{-3}$ Torr $l /$ $\sec$ 程度以下のリークを止めることが可能，硬化は $200^{\circ} \mathrm{C}$ に加熱すれば30分で, 又, 常温でも2 3 日で硬 化し, 液体へリウムの温度から， $450^{\circ} \mathrm{C}$ と広範囲で使用 可能. 正式に修理するための，硬化したシーラントの除 去も簡単に出来る ${ }^{28,29)}$.
表4.4 カルレッツ主要特性表27)

\begin{tabular}{|c|c|c|}
\hline & 単位 & 4079 \\
\hline 比 & - & $1.9 \sim 2.0$ \\
\hline 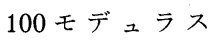 & $\mathrm{kgf} / \mathrm{mm}$ & 66.8 \\
\hline 破断時の引張り & $\mathrm{kgf} / \mathrm{mm}$ & 134 \\
\hline 強 さ & KgI/ mm & \\
\hline 破断時の伸び & $\%$ & 140 \\
\hline 硬度 & ショアーA & 75 \\
\hline 熱膨 張 & $/{ }^{\circ} \mathrm{C}$ & $2.3 \times 10^{-4}$ \\
\hline 摩 耗 抵 抗 & & バイトンに同じ \\
\hline 引き裂き強度 & & " \\
\hline
\end{tabular}

エポキシ系樹脂のシーラントは, 接着剤, 充てん剤と しても使觉，従って相当大きなリークが止められる. 更 にもっと違った利用も可能であるが，超高真空用として は，最小量に止めるべきである．表4.5に実際のシーラ ントの特性等を示す，超高真空で使用が可能とは言って もあくまでも暫定措置である。

\section{〔文献〕}

1) E. D. Erikson, T. G. Beat, D. D. Berger and B. A. Fragier: J. Vac. Sci. Technol., A2 (1984) 206.

2) M. Albertin, P. Duval, G. Gorians and J. M. Pacquet: Industrial Research \& Development, May 1981 163.

3) S. S. Rosenblum: J. Vac. Sci. Technol., A4 (1986) 107.

4) J. Santhanam and P. Vijendran: Vacuum, 32 (1982) 487.

5) Smt. J. Santhanam and P. Vijendran: Vacuum, 29 (1979) 237. 


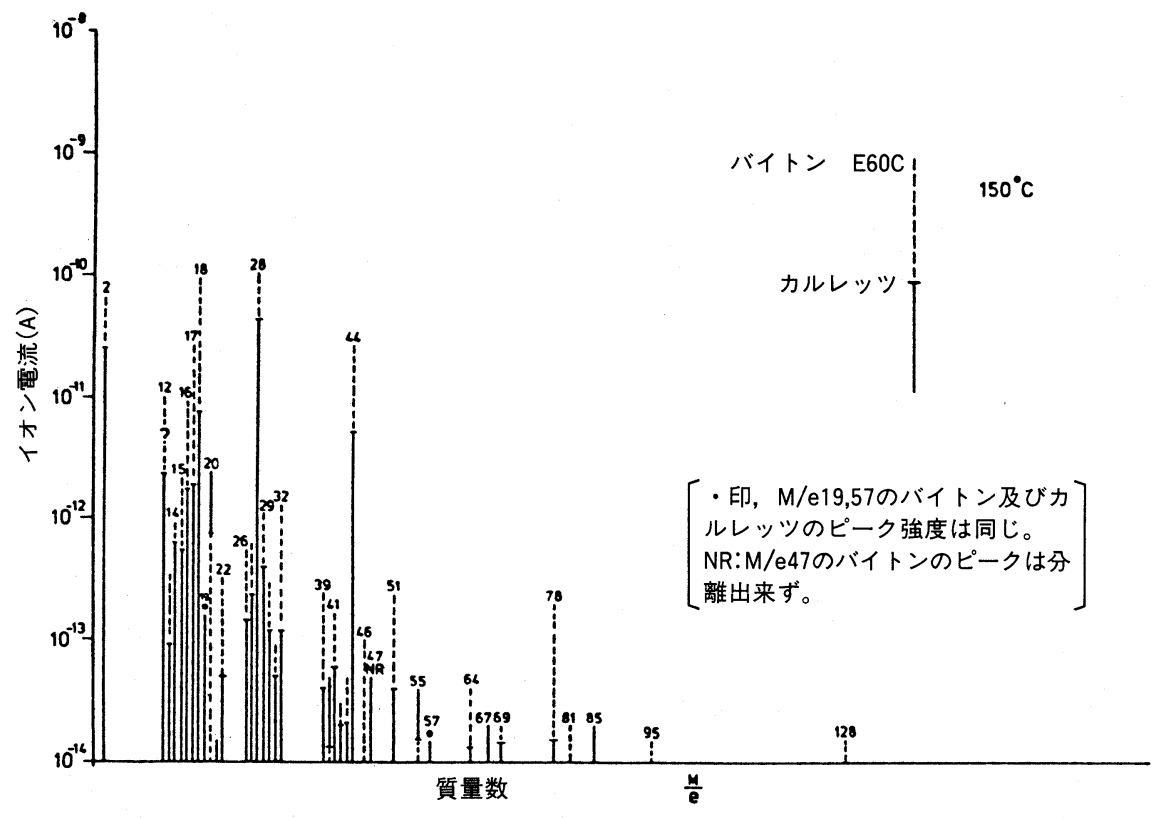

図4.5 バイトン E60C とカルレッツの残留ガススペクトル25)

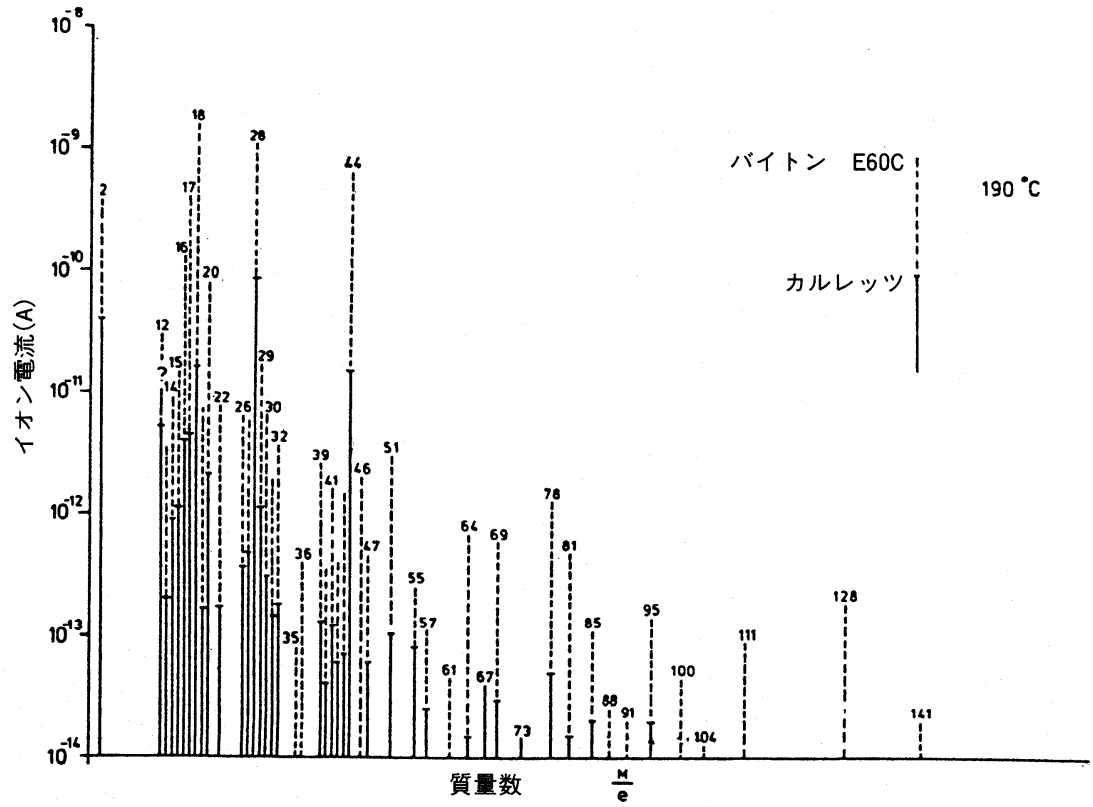

図4.6 バイトン E60C とカルレッツの残留ガススペクトル25)

6）山口章三郎著「エンジニアリングプラスチック活 用ハンドブック」, 技術評論社 (1952).

7) Y. Shapira and D. Litchman: Vacuum Physics and Technology, ed. by G. L. Weisslee and R. W. Carlson (Academic N.Y 1979) Chap. 8.
8）西村 允：機械の研究, 37 (1985) 545.

9) K. F. Poole and M. M. Michaelis: Vacuum, 30 (1980) 415.

10) P. J. Silverman: J. Vac. Sci. Technol, A2 (1984) 76.

11）大㭇祐夫, 赤石憲也：真空, 18 (1975) 127. 
表4.5 各種シーラントの特性表 30 31)

\begin{tabular}{|c|c|c|c|}
\hline & Vac seal & Torr seal & スーパーバックシール \\
\hline 最高使用温度（ㄷ） & 450 & 120 & 150 \\
\hline 定常重量損失（g/ $\mathrm{cm}^{2} / \mathrm{h} ）$ & $1.6 \times 10^{-8}$ & $2.6 \times 10^{-7}$ & $1 \times 10^{-8}\left(\right.$ Torr $\left.\cdot l / \mathrm{sec} \mathrm{cm}^{2}\right)$ \\
\hline シール可能リーク量 & $<4 \times 10^{-3}$ & 目に見えるもの & 左に同じ \\
\hline 使用対象 & 金属ガラス & 金属ガラスセラミックス & 左に同じ \\
\hline 除去法 & $500^{\circ} \mathrm{C}$ に加熱 & チトン・エステル系 & 左に同じ \\
\hline 硬化時間 & 30 分 $/ 200^{\circ} \mathrm{C}$ & 30 分 $/ 60^{\circ} \mathrm{C}$ & 30 分 $/ 100^{\circ} \mathrm{G}$ \\
\hline $\begin{array}{l}\text { 塗布後シールを確認出来る } \\
\text { までの時間 }\end{array}$ & 数秒後 & 即時 & 左に同じ \\
\hline 容器 & 瓶入 & チューブ & パッケージ \\
\hline 原材料 & シリコン系 & エポキシ系 & エポキシ系 \\
\hline メーカー & Space Enviroment Lab. Co. & Varian & 日電アネルバ(侏) \\
\hline
\end{tabular}

12) N. G. Perkins: J. Vac. Technol., 10 (1973) 543.

13) H. Miyake, M. Matsuyama, K. Ashida and K.

Watanabe: J. Vac. sci. Technol., A1 (1983) 1447.

14）本田紀将, 河内正治 : 工業材料, 31 No. 5, 35.

15）デュポン社「ベスペル」技術資料による.

16） R. N. Peacock: J. Vac. Sci. Technol., 17 (1980) 330.

17）横倉賢治, 椛沢 稔: 真空, 24 (1981) 399.

18) G. F. Weston: Vacuum, 34 (1984) 619.

19) L. de Gsernatony: Vacuum, 16 (1966) 13.

20) L. de Gsenatony: Vacuum, 16 (1966) 129.

21) L. de Csernatony: Vacuum, 16 (1966) 247.

22) L. de Csernatony: Vacuum, 16 (1966) 427.

23) L. de Csernatony and D. J. Crawley: Vacuum, 17 (1967) 551.

24) L. de Chernatony: Proc. 7 th Intern, Vac. Congr. \& 3 rd Intern. Cont. Solid Surfaces Vienna (1977) 255.
25) L. de Chernatony: Vacuum, 27 (1977) 605.

26) M. F. Zabielski and P. R. Blaszuk: J. Vac. Technol., 13 (1976) 644.

27）デュポン社「カルレッツ」技術資料による.

28) Space Envivoment Laboratoriss Inc. VACSEAL ${ }^{\circledR}$ カ タログより。

29) B. R. F. Kendall: J. Vac. Sci. Technol., 20 (1982) 248.

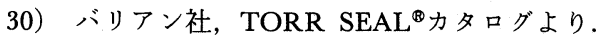

31）日電アネルバ，「スーパーバックシール」カタログ より.

32) A. K. Gupta, K. V. Kurup, J. Santhanam and P. Vijendran: Vacuum, 27 (1977) 61.

33) R. Sridharan, V. G. Shah and Pradeep Mohan: Vacuum, 30 (1980) 81.

34）小林正明：工業材料, 31 No. 5, 31 . 